\title{
Performance Investigation of a Gasifier and Gas Engine System Operated on Municipal Solid Waste Briquettes
}

\author{
Nigran Homdounga, ${ }^{a}$, Nattawud Dussadee ${ }^{a}$, Kittikorn Sasujita, Tanongkiat \\ Kiatsiriroat $^{\mathrm{b}}$ and Nakorn Tippayawong ${ }^{\mathrm{b}}$
}

\author{
a School of Renewable Energy, Maejo University, Chiang Mai 50290, Thailand \\ ${ }^{b}$ Department of Mechanical Engineering, Chiang Mai University, Chiang Mai 50200, Thailand
}

\begin{abstract}
Municipal solid waste (MSW) and charcoal can be used as a substitute fuel in a gas engine. In this work, performance of a downdraft gasifier and gas engine system operated on MSW briquette fuel was investigated. Experimental test was carried out on a 62 $\mathrm{kW}$, four-cylinder, naturally aspirated engine coupled to a $20 \mathrm{~kW}$ dynamometer. The downdraft gasifier was used to generate producer gas from MSW briquettes and charcoal. The engine load was varied between 1.5-9.0 kW. Biomass consumption, producer gas production, cold gas efficiency, thermal efficiency of the gas engine, carbon monoxide (CO), hydrocarbon (HC) emissions and exhaust temperature were evaluated. The MSW briquette fuelled operation was compared against that with charcoal. It was found that, the use of MSW briquette led to lowering performance of the downdraft gasifier and gas engine system, in comparison with the use of charcoal. Maximum cold gas and thermal efficiencies obtained were $64.6 \%$ and $16 \%$ at $4.5 \mathrm{~kW}$ and $9 \mathrm{~kW}$ loading, respectively. The CO and HC emissions of the gas engine operated on MSW briquettes were higher than that on charcoal, while the exhaust temperatures were similar. C2019. CBIORE-IJRED. All rights reserved
\end{abstract}

Keywords: biomass, gas engine, gasification, MSW, densified fuel, renewable energy

Article History: Received: January 11, 2019; Revised: March 7, 2019; Accepted: June 5, 2019; Available online: July 15, 2019 How to Cite This Article: Homdoung, N., Dussadaee, N., Sasujit, K., Kiatsiriroat, K. and Tippayawong, N. (2019) Performance investigation of a gasifier and gas engine system operated on municipal solid waste briquettes. Int. Journal of Renewable Energy Development, 8(2), $179-184$. https://doi.org/10.14710/ijred.8.2.179-184

\section{Introduction}

Management of municipal solid waste (MSW) or other solid wastes is one of the major challenges for Thailand (Tippayawong and Tippayawong, 2017). From the government survey, it was found that MSW generation rate was about less than $1 \mathrm{~kg} /$ capita/day. Consequently, there are more than $2400 \mathrm{MSW}$ pits in the country (Chiemchaisri et al., 2007). At present, the reduction technology adopted to reduce MSW are direct burning and briquette fuel production. The burning of MSW focuses on reducing the volume of waste and that can be easily buried or stored, while the briquetting or densification method focuses on production of alternative fuels to replace fossil fuels in factories (Tippayawong et al., 2018; Piboon et al., 2017; Wongsiriamnuay and Tippayawong, 2015). However, the use of direct combustion to MSW has low efficiency, with average value between 15-25\% (Department of Industrial Promotion, 2007), while the gasification technology can offer the average efficiency in a range of $60-75 \%$ (Homdoung et al., 2012; Punnarapong et al., 2017). The use of briquette fuel to generate the producer gas and operate on gas engines for electricity production is very attractive. Importantly, this approach can help reduce imported energy from overseas.

The study about utilization of MSW briquette fuel for energy production can be described as follows. The main material for producing MSW briquettes was from wood chips, papers, plastics, textile waste or other combustible materials (Krizan et al., 2011; Shrestha et al., 2011). Normally, the MSW briquettes have an average density of $900-1200 \mathrm{~kg} / \mathrm{m}^{3}$ (Prasityousil et al., 2013). Binders may be used in MSW briquettes to increase the bulk density, (Shyamalee et al., 2015; Bhoumick et al., 2016). The average heating value of MSW briquette fuel was in a range of 13.6-16.6 MJ/kg (Romallosa et al., 2016).

In actual implementation, most MSW briquette fuel will be used in industrial plants namely direct combustion system and gasification process. In direct combustion application, majority of the briquette fuel will be used to produce cement, steam and another thermal energy (Chatziaras et al., 2016), while gasification process will be used to produce the producer gas or syngas for electricity generation (Nasner et al., 2017). The thermal efficiency in the direct combustion process obtained was around 15-20\% (Raju et al., 2014), while 
Citation: Homdoung, N., Dussadaee, N., Sasujit, K., Kiatsiriroat, K. and Tippayawong, N. (2019) Performance investigation of a gasifier and gas engine system operated on municipal solid waste briquettes. Int. Journal of Renewable Energy Development, 8(2),179-184, doi.org/ijred.8.2.179-184

P a g e 180

the gasification process can achieve between $60-70 \%$, the calorific value of producer gas was between $4-6 \mathrm{MJ} / \mathrm{Nm}^{3}$ (Dzombo et al., 2013). The gas engine can be operated with producer gas well (Sridhar et al., 2001; Homdoung et al., 2014). The gas engine was adopted from a compression ignited engine and modified into a spark ignited engine at high compression ratio. Charcoal was used in gasification and calorific value of the producer gas was in a range of 4.64-5.00 $\mathrm{MJ} / \mathrm{Nm}^{3}$. Nevertheless, the engine power was expected to decrease by more than $50 \%$ (Munoz et al., 1999). The cause of brake power reduction was due to the fact that the energy density of producer gas was low (Sridhar et al., 2001; Mustafi et al., 2006). However, the engine performance can be improved by modifications of existing engines, including changing the combustion chamber, increasing compression ratio and ignition timing adjustment (Homdoung et al., 2015). The emissions of producer gas engine were similar to original fuel. The $\mathrm{CO}$ and $\mathrm{HC}$ emissions from gas engines were slightly higher, but lower than standards when use at the optimum condition.

From the literature review, the operation of MSW briquette fuel in gasifier-engine setup was quite limited. Thus, the objective of this research was to investigate the use of MSW briquette fuel in a downdraft gasifier to generate a fuel gas and subsequently fed to a gas engine. Performance of the gasifier and gas engine system was evaluated in terms of biomass fuel consumption, producer gas production, cold gas efficiency, thermal efficiency of the gas engine, exhaust emissions and temperature.

\section{Materials and Methods}

\subsection{Gasifier and gas engine}

Figure 1 shows the overall view of the engine test rig. It consisted of a gasification reactor and a spark ignited engine adapted to operate on producer gas from MSW gasification. The gasifier system consisted of a downdraft gasifier, a gas cooler and a gas conditioning unit including a cyclone, a venturi and packed bed scrubber, biomass and paper filters. Reduction of temperature and removal of tar and particulate were done by closed-loop water recirculation, with the detail shown in Table 1. Specification of the gasifier used may be found in our previous work (Homdoung et al., 2012).

Table. 1

Specifications of the gasifier fuelled with biomass

\begin{tabular}{ll}
\hline Parameters & \multicolumn{1}{c}{ Specification } \\
\hline Gasifier type & Downdraft \\
Gasifier capacity & MSW briquette: $100-110 \mathrm{~kg}$ \\
Feed system & Charcoal: $35-45 \mathrm{~kg}$ \\
Cooling system & Batch feeding \\
& Water \\
Cleaning system & Cyclone, Venturi and pack \\
& bed scrubber, Fabric and \\
Biomass size & paper filters \\
Producer gas temperature & $25-50 \mathrm{~cm}$ \\
\hline
\end{tabular}

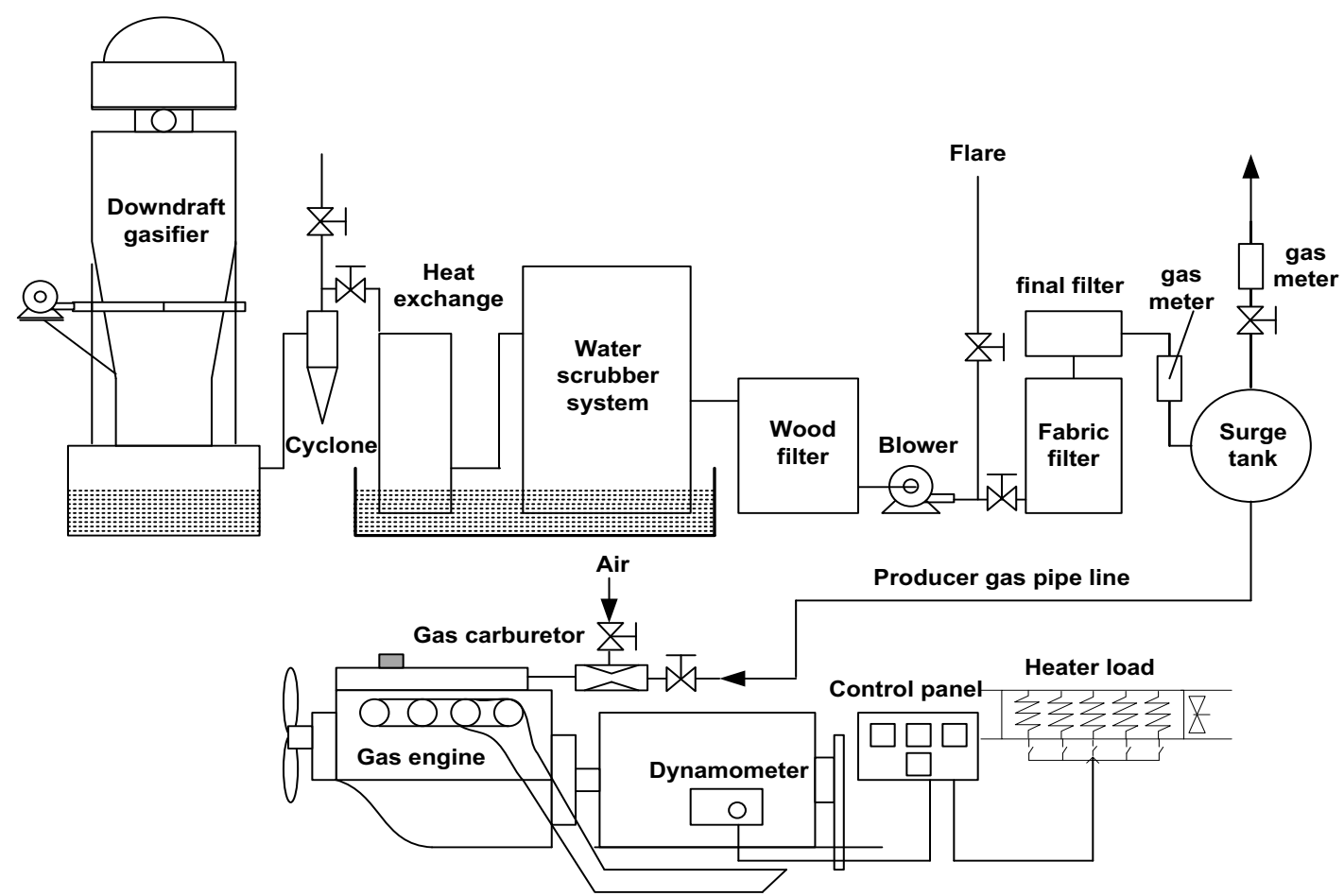

Figure 1. Schematic diagram of the experimental setup

The engine used in this work was a $62 \mathrm{~kW}$ (82 hp), naturally aspirated gas engine. It was a four-stroke, fourcylinder engine with a bore $\times$ stroke of $83 \times 73.7 \mathrm{~mm}$, and a compression ratio of $8.8: 1$. The engine was coupled to a $20 \mathrm{~kW}$ alternator to generate $200-240 \mathrm{~V}$ electricity at 60
Hz. The gas mixer used was similar to a carburettor. The velocity of producer gas flow through a venturi will draws air into the main flow and they were mixed before entering the cylinder. Specifications of the gas engine are given in Table 2. 
Table. 2

Specifications of the gas engine fuelled with producer gas

\begin{tabular}{ll}
\hline Parameters & Specification \\
\hline Type & SI, 4-stroke/cylinders, gas \\
Engine rating $(\mathrm{kW})$ & $61.4(82 \mathrm{HP})$ \\
Bore $(\mathrm{mm})$ & 83 \\
Stroke $(\mathrm{mm})$ & 73.7 \\
Displacement $(\mathrm{CC})$ & 1595 \\
Compression ratio & $8.8: 1$ \\
Advance timing & $30^{\circ}$ BTDC \\
Alternator rating $(\mathrm{kW})$ & 20 \\
Rated output & $20 \mathrm{~kW} @ 1500 \mathrm{rpm}$ \\
Loading device & Electrical heater \\
\hline
\end{tabular}

\subsection{MSW briquette fuel}

The production of MSW briquette fuel was based on densification of the mixture between paper, plastic and biomass at a mass ratio of $1: 1: 1$, with binding agent made from cassava starch and lime. Figure 2 shows the resulting MSW briquettes as well as its components (paper, plastic and biomass).

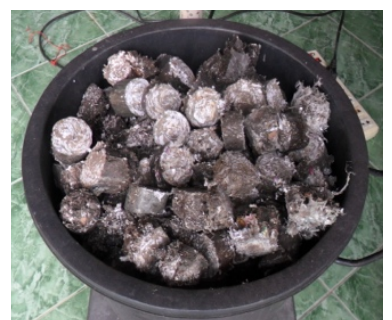

MSW

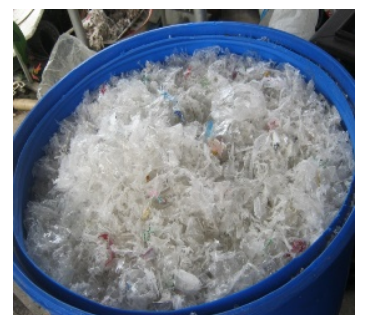

Plastic

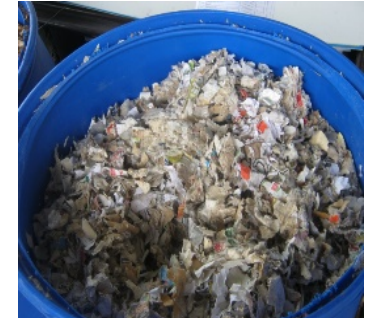

Paper

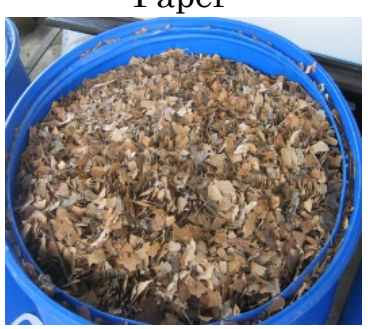

Biomass
Figure 2. MSW briquette fuel from paper, plastic and biomass

The density of MSW briquette fuel was about 902 $\mathrm{kg} / \mathrm{m}^{3}$ on average, and $2-4 \%$ moisture content. Diameter of the briquette fuel was $5 \mathrm{~cm}$ on average and cut into 2.5-5.0 $\mathrm{cm}$ prior to feeding in the downdraft gasifier. The size of the charcoal used was about $2.5 \times 2.5 \times 2.5$ to $5 \times 5 \times 5$ $\mathrm{cm}^{3}$, in accord with the FAO (FAO, 1986), while the density and moisture content were found to be 250-300 $\mathrm{kg} / \mathrm{m}^{3}$ and $7 \%$, respectively. Analysis of both fuels were conducted based on ASTM C373-88 and ASTM D 2016-74 standards. The lower heating value of the MSW briquette fuel and charcoal were about $26,000 \mathrm{~kJ} / \mathrm{kg}$ and 28,500 $\mathrm{kJ} / \mathrm{kg}$, respectively.

\subsection{Test procedures and data analysis}

The test conditions were as follows: ambient pressure was $0.92 \mathrm{kPa}$; density of air was $1.1 \mathrm{~kg} / \mathrm{m}^{3}$ and the ambient temperature during the testing period was $310 \pm$ 3K. A load bank was connected to test the engine generator set. Measurements on current, voltage, frequency and fuel consumption were carried out. The static pressures were monitored using water tube manometers. The temperature of the producer gas from both fuels after reduction zone was about $500-600^{\circ} \mathrm{C}$. The hot producer gas was allowed to pass through the cooler where its temperature was reduced to room condition. The cooled and moist gas was then passed through the filters to remove tar and other particulate matter.

A gas analyzer from Agilant 6890 gas chromatography was used to measure the mole fractions of $\mathrm{CO}, \mathrm{H}_{2}, \mathrm{CH}_{4}, \mathrm{CO}_{2}$ and $\mathrm{N}_{2}$ in the producer gas. Average composition of fuel gas from gasification of the MSW briquette fuel was found to be $\mathrm{CO}=8.35 \pm 2 \%, \mathrm{H}_{2}=10.23$ $\pm 2 \%, \mathrm{CH}_{4}=3.52 \pm 0.5 \%, \mathrm{CO}_{2}=17.7 \pm 2 \%$ and the rest $\mathrm{N}_{2}$, while for the charcoal, $\mathrm{CO}=30.86 \pm 2 \%, \mathrm{H}_{2}=8.2 \pm 2 \%$, $\mathrm{CH}_{4}=0.32 \pm 0.5 \%, \mathrm{CO}_{2}=4.68 \pm 2 \%$. The biomass and producer gas consumption were measured at varying engine loads between $1.5-9.0 \mathrm{~kW}$. The producer gas and air flow rates were measured using gas flow meters. Afterwards, biomass consumption, producer gas production, cold gas efficiency, thermal efficiency of the gas engine, $\mathrm{CO}, \mathrm{HC}$ emissions and exhaust temperature were evaluated. The cold gas efficiency and brake thermal efficiency of the gas engine were evaluated using the following equations. The cold gas efficiency of downdraft gasifier was given by (Murakami et al., 2013)

$$
\eta_{g}=\frac{m_{g} \times C V_{g}}{m_{b} \times L H V_{b}}
$$

Where $m_{g}$ is producer gas flow rate $\left(\mathrm{m}^{3} / \mathrm{s}\right), C V_{g}$ is the calorific valve of producer gas, $\left(\mathrm{MJ} / \mathrm{Nm}^{3}\right) . m_{b}$ is biomass consumption rate $(\mathrm{kg} / \mathrm{s})$ and $L H V_{b}$ is the lower heating valve of the producer gas, $\left(\mathrm{MJ} / \mathrm{Nm}^{3}\right)$.

The brake thermal efficiency of the gas engine can be calculated by the following relation (Heywood, 1989) which the equation can be used for another gas fuel (Haryanto et al., 2017),

$$
B T E=\frac{P_{b}}{m_{g} \times C V_{g}} \times 100
$$

Where $P_{b}$ is brake power $(\mathrm{kW})$.

\section{Results and Discussion}

\subsection{Biomass consumption}

Figure 3 shows the consumption of MSW briquette fuel and charcoal when operated on the downdraft gasifier. Consumption of both biomass feedstocks was increased with increasing engine load. The use of MSW briquette fuel in the gasifier appeared to be higher than charcoal. This was due to the fact that the MSW briquette fuel was deformed during the reaction and partially blocked the air flows, hindering the gasification reaction. Fraction of obtained combustible gases became smaller, hence smaller heating value of the gas. Maximum consumption of both fuels was obtained at 9 $\mathrm{kW}$ of engine loading. They were between $13-15 \mathrm{~kg} / \mathrm{h}$.

\subsection{Producer gas generation}

Figure 4 shows effect of engine loading on producer gas flow rate. The generation of producer gas was found 
to increase with increasing engine load. The highest producer gas from MSW briquette fuel was obtained at 60 $\mathrm{m}^{3} / \mathrm{h}$, while the producer gas from charcoal was only 40 $\mathrm{m}^{3 / h}$ occurring at higher engine load. The gas engine consumed the producer gas from MSW briquette fuel at higher amount than the charcoal, with average of $33 \%$ higher. Since the calorific value of the producer gas from MSW briquette was lower than that from charcoal, when the engine run at full load, the producer gas of MSW was consumed more.

\subsection{Cold gas efficiency}

Figure 5 shows the cold gas efficiency when using MSW briquette fuel and charcoal. The cold gas efficiency did not exhibit large variation with engine load. At high engine load, the cold gas efficiency was observed to decrease slightly. Maximum cold gas efficiency for charcoal was about $70 \%$, while for the MSW briquette fuel, it was about $65 \%$, occurring at $4.5 \mathrm{~kW}$ of engine load. Reduction in cold gas efficiency of MSW briquette fuel occurred when operated on plastics (Kungkajit et al., 2015). The use of charcoal to generate producer gas can provide higher cold gas efficiency than MSW briquette fuel. However, when compared with other downdraft gasifiers, the average cold gas efficiency was similar, in a range of $62-69 \%$ using agricultural waste (Chawdhurya et al., 2011).

\subsection{Thermal efficiency}

The thermal efficiency of the producer gas engine operated on MSW briquette fuel and charcoal are shown in Figure 6. Increase in engine load led to increase in thermal efficiency. The highest thermal efficiency occurred at $7.5 \mathrm{~kW}$. Drop in the thermal efficiency was caused by incomplete combustion in the engine cylinder (Lekpradit et al., 2009). The use of producer gas from charcoal showed higher thermal efficiency than that from MSW briquette. This may be due to higher producer gas flow rates and lower calorific value of the producer gas. Maximum thermal efficiencies of the gas engine operated on MSW briquette fuel and charcoal were calculated to be 16 and $17.3 \%$, respectively. Both were achieved at engine load of $7.5 \mathrm{~kW}$.

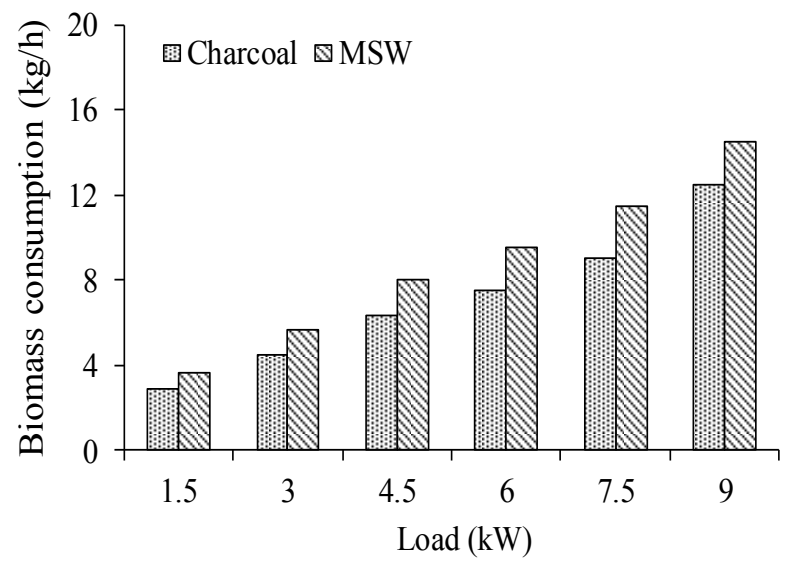

Figure 3. biomass consumption

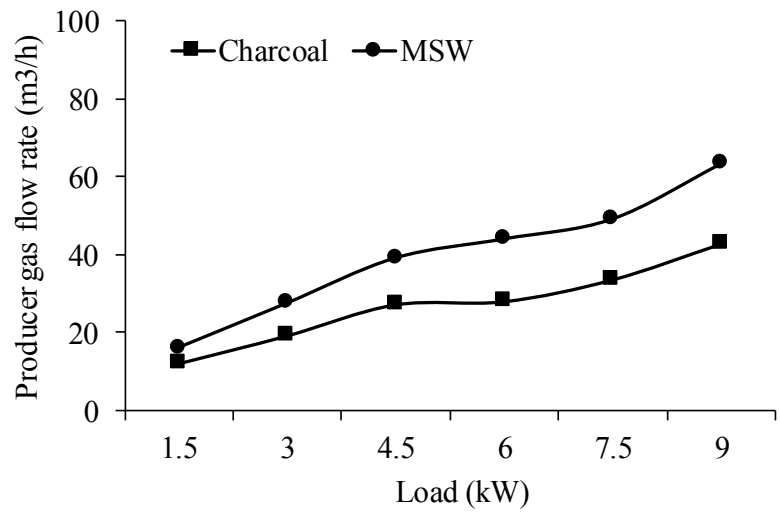

Figure 4. producer gas flow rate

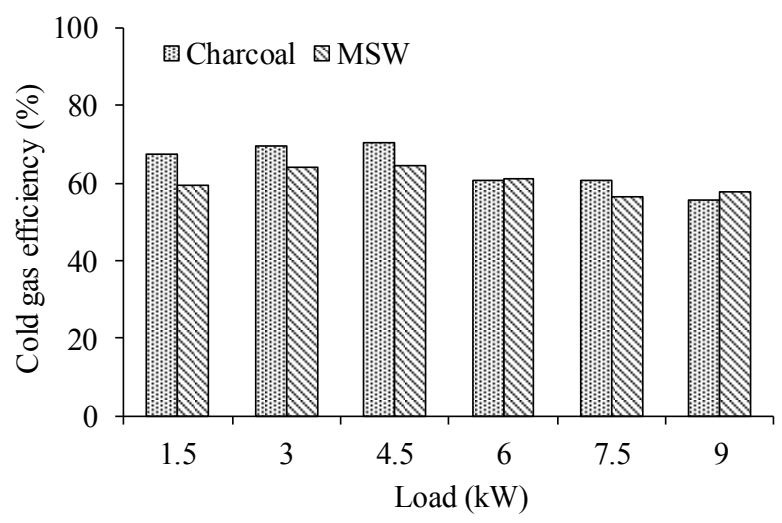

Figure 5. cold gas efficiency

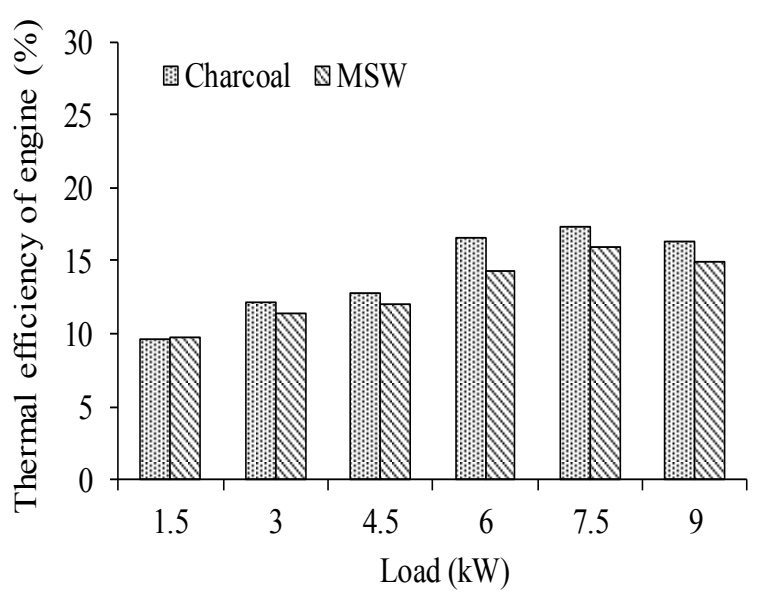

Figure 6. thermal efficiency of the gas engine

\subsection{CO and HC emissions}

High $\mathrm{CO}$ emission from the gas engine was due to incomplete combustion which in turn caused by rich airfuel mixture ratio (Schirmer et al., 2017). Figure 7 shows the $\mathrm{CO}$ emission from the gas engine operated on producer gas from MSW briquette fuel and charcoal. Increasing engine load resulted in increased $\mathrm{CO}$ emission due to insufficient oxygen available for combustion (Homdoung et al., 2015). The CO emission from the use of MSW briquette fuel was higher than that from the use of 
charcoal. The highest CO emission from MSW briquette occurred at maximum engine load. At low engine loads, the CO emission was found to be below Thailand pollution control regulations.

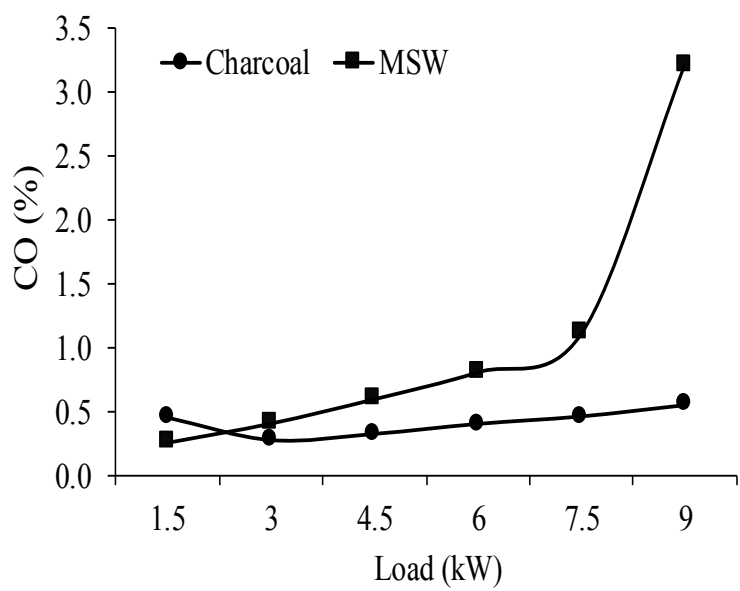

Figure 7. $\mathrm{CO}$ emission from the gas engine

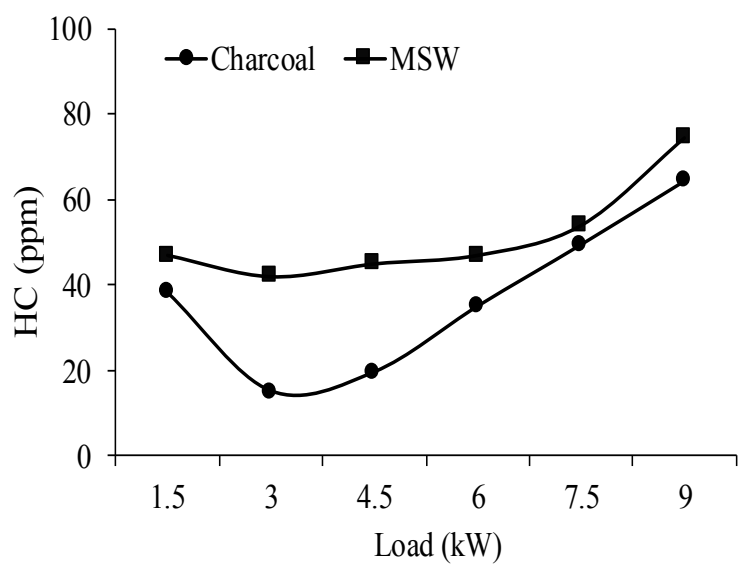

Figure 8. HC emission from the gas engine

Figure 8 shows the $\mathrm{HC}$ emission from the gas engine when using MSW briquette fuel and charcoal. Low HC emission occurred at 3.0-4.5 $\mathrm{kW}$ engine loading and tended to increase with increasing engine load. The HC emission from the gas engine using MSW briquette fuel was higher than that from charcoal. This was something to do with the temperature of cylinder of the gas engine may be slightly lower, caused by the lower calorific value of the producer gas, compared to charcoal operation (Ganesan, 2002). At the load between 1.5 to $3 \mathrm{~kW}$, the gas engine appeared to have complete combustion. The cylinder of engine had high temperature, hence lower $\mathrm{HC}$ emission. The lower HC emission from the gas engine operated on MSW briquette fuel was between 42-45 ppm, while for charcoal, the $\mathrm{HC}$ emission was $15-19.5 \mathrm{ppm}$. It should be noted that the HC emission obtained was below Thailand standards, normally the HC emission of a spark ignition engine should be less than 200 ppm (Thailand Pollution Control Department, 2018).

\subsection{Exhaust temperature}

Figure 9 shows the exhaust temperature of the gas engine. Increasing engine load was found to lead to increase in exhaust temperature. Change in exhaust temperature of both fuels was similar. The exhaust temperature of the gas engine was decreased due to poor combustion in the engine cylinder (Ghazikhani et al., 2014). The exhaust temperature of the gas engine when using MSW briquette fuel and charcoal was in a range of $280-350^{\circ} \mathrm{C}$ and $290-350^{\circ} \mathrm{C}$, respectively.

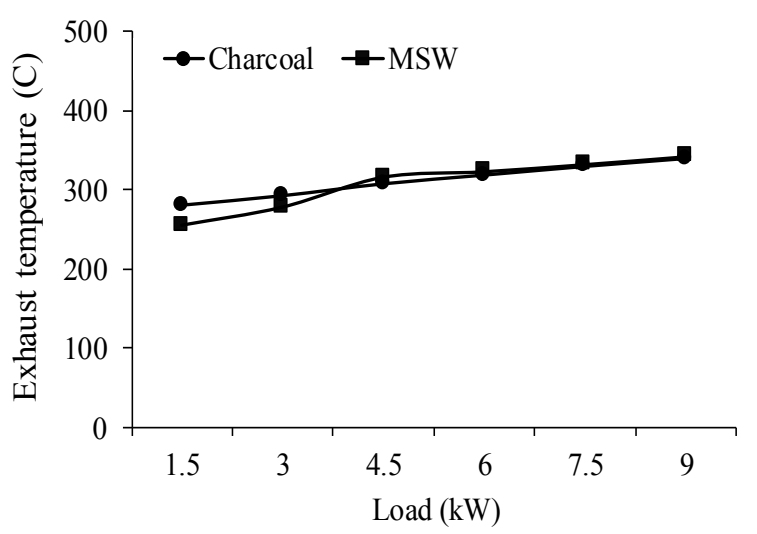

Figure 9. Exhaust temperature of the gas engine

\section{Conclusions}

The MSW briquette fuel may be used to power the gas engine via gasification process. The average cold gas efficiency from gasification of the MSW briquette fuel was about $65 \%$ at $45 \mathrm{~kW}$ of engine load. This was lower than that using charcoal by about $8 \%$. The maximum thermal efficiency of the gas engine was $16 \%$ when using MSW briquette, while it was $17 \%$ for charcoal. The CO and HC emissions of the gas engine obtained were below the pollution control norms.

\section{Acknowledgements}

We would like to thank the supports from the National Research Council of Thailand (NRCT) under the Thailand-China Cooperation Program (Performance Analysis of Power Generation by Producer Gas from RDF5) and the Office of Agricultural Research and Extension, Maejo University 2016-2018. The Energy Research Center and School of Renewable Energy, Maejo University are thanked for providing facilities and test equipment.

\section{References}

Bhoumick, M.C., Sarker, N.C., Hasan, Md.M. \& Roy, B.K. (2016) Conversion of waste plastic into solid briquette in combinationwith biomass: Bangladesh perspective. International Advance Research Journal in Science, Engineering and Technology, 3, 142-146

Chatziaras, N., Psomopoulos, C.S. \& Themelis, N.J. (2016) Use of waste derived fuels in cement industry: a review. Management of Environmental Quality: An International Journal, 27, 178 - 193. 
Chawdhurya, M.A. \& Mahkamov, K. (2011) Development of a small downdraft biomass gasifier for developing countries. Journal of Science Research, 3, 51-64.

Chiemchaisri, C., Juanga, J.P. \& Visvanathan, C. (2007) Municipal solid waste management in Thailand and disposal emission inventory. Environmental Monitoring and Assessment, 135, 13-20.

Department of Industrial Promotion, Ministry of Industry. (2007) Thermal energy efficiency improvement handbook, https://www.eccj.or.jp/cooperation/1-1-1/02.pdf Accessed on 9 October 2018

Dzombo, D.M., Kiplimo, R. \& Kiplagat, J.K. (2013) Use of biomass gas in running internal combustion engine to generate electricity -A review. Proceedings of 2013 Mechanical Engineering Conference on Sustainable Research and Innovation, 5, 89-95.

Food and Agriculture Organization (FAO). (1986) Wood gas as engine fuel. Mechanical wood products branch forest. Italy. 1986

Ganesan, V. (2002) Internal Combustion Engines. Tata McGrawHill, India.

Ghazikhani, M. Hatami, M. Safari, B. \& Ganji, D.D. (2014) Experimental investigation of exhaust temperature and deliveryratio effect on emissions and performance of a gasoline- ethanol two-stroke engine. Case Studies in Thermal Engineering, 2, 82-90.

Haryanto, A., Marotina, F., Triyonoa, S., Hasanudin, U. (2017) Developing a family-size biogas-fueled electricity generating system. International Journal of Renewable Energy Development, 6 (2), 111-118.

Heywood, J.B. (1989) Internal Combustion Engine Fundamentals. McGraw-Hill, Singapore.

Homdoung, N., Tippayawong, N. \& Dussadee, N. (2012) Performance investigation of a smallengine fueled with producer gas and diesel in dual fuel operation. Proceedings of the 3rd TSME International Conference on Mechanical Engineering. October 2012, Chiang Rai, Thailand.

Homdoung, N., Tippayawong, N. \& Dussadee, N. (2014) Effect of ignition timing advance on performance of a small producer gas engine. International Journal of Applied Engineering Research, 9, 2341-2348.

Homdoung, N., Tippayawong, N. \& Dussadee, N, (2015) Performance and emissions of a modified small engine operated on producer gas. Energy Conversion and Management, 96, 286-292.

Krizan, P., Matus, M., Soos, L., Kers, J., Peetsalu, P., Kask, Ü., \& Menind, A. (2011) Briquetting of municipal solid waste by different technologies in order to evaluate its quality and properties. Agronomy Research Biosystem Engineering, 1, 115-123.

Kungkajit, C., Prateepchaikul, G. \& Kaosol, T. (2015) Influence of plastic waste for refuse-derived fuel on downdraft gasification. Energy Procedia, 79, $528-535$.

Lekpradit, T., Tongorn, S., Nipattummakul, N., \& Kerdsuwan, S., (2009) Study on advanced injection timing on a dualfuel diesel engine. Journal of Metals, Materials and Minerals, 18, 169-173.

Munoz, M., Moreno, F., Morea-Roy, J., Ruiz, J. \& Arauzo, J. (2000) Low heating value gas on spark ignition engines. Biomass and Bioenergy, 18, 431-439.

Murakami, T. Asai, M. \& Suzuki, Y. (2013) Optimized approach of high cold gas efficiency of woody biomass in a fluidized bed gasifier with triple-beds. Journal of the Japanese Society for Experimental Mechanics, 13, 30-34.

Mustafi, N.N., Miraglia, Y.C., Raine, R.R. Bansal, P.K. \& Elder, S.T. (2006) Spark-ignition engine performance with 'Powergas' fuel (mixture of $\mathrm{CO} / \mathrm{H} 2$ ): A comparison with gasoline and natural gas. Fuel 85, 1605-1612.

Nasner, A.M.L., Lora, E.E.S., Palacio, J.C.E., Rocha, M.H., Restrepo, J.C., Venturini, O.J. \& Ratner, A. (2017) Refuse derived fuel (RDF) production and gasification in a pilot plant integrated with an Otto cycle ICE through Aspen plus TM modelling: Thermodynamic and economic viability. Waste Management, 69, 187-201.

Piboon, P., Tippayawong, N., \& Wongsiriamnuay, T. (2017) Densification of corncobs using algae as a binder. Chiang Mai University Journal of Natural Sciences, 16(3), 175182.

Pollution Control Department. (2018) Quality of air and sound norms, http://www.pcd.go.th/info_serv/reg_std_ airsnd02.html, Accessed on 3 October 2018.

Prasityousil, J., \& Muenjina, A. (2013) Properties of solid fuel briquettes produced from rejected material of municipal waste composting. Procedia Environmental Sciences, 17, $603-610$.

Punnarapong, P., Sucharitakul, T., \& Tippayawong, N. (2017) Performance evaluation of premixed burner fueled with biomass derived producer gas. Case Studies in Thermal Engineering, 9, 40-46.

Raju, A. \& Madhu, S. (2014) High efficiency and less pollutant power plants using biomass mixed with municipal solid waste and coal dust. International Journal of Research in Computer and Communication Technology, 3, 1367-1373.

Romallosa, A.R.D. \& Kraft, E. (2017) Feasibility of biomass briquette production from municipal waste streams by integrating the informal sector in the Philippines. Resources, 6, 1-19.

Schirmer, W.N. Olanyk, L.Z. Guedes C.L.B. Quessada, T.P. Ribeiro, C.B. \& Capanema, M.A. (2017) Effects of air/fuel ratio on gas emissions in a small spark-ignited non-road engine operating with different gasoline/ethanol blends. Environmental Science and Pollution Research, 24, 2035420359.

Shrestha, A., \& Singh, R.M. (2011) Energy recovery from municipal solid waste by briquetting process: Evaluation of physical and combustion properties of the fuel. Nepal Journal of Science and Technology, 12, 238-241.

Shyamalee, D., Amarasinghe, A.D.U.S. \& Senanayaka, N.S. (2015) Evaluation of different binding materials in forming biomass briquettes with saw dust. International Journal of Scientific and Research Publications, 5, 1-8.

Sridhar, G., Paul, P.J. \& Mukunda, H.S. (2001) Biomass derived producer gas as a reciprocating engine fuel-an experimental analysis. Biomass and Bioenergy, 21, 61-72.

Tippayawong, K. Y., \& Tippayawong, N. (2017) Fuel recovery from thermal processing of post-consumer footwear waste. Energy Engineering, 114(3), 7-16.

Tippayawong, N., Jaipa, C., \& Kwanseng, K. (2018) Biomass pellets from densification of tree leaf waste with algae. Agricultural Engineering International: CIGR Journal, 20(4), 119-125.

Wongsiriamnuay, T., \& Tippayawong, N. (2015) Effect of densification parameters on property of maize residue pellets. Biosystems Engineering, 139, 111-120.

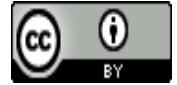

2019. This article is an open access article distributed under the terms and conditions of the Creative Commons Attribution (CC BY) license (http://creativecommons.org/licenses/by/4.0/). 